Arab Univ. J. Agric. Sci., Ain Shams Univ., Cairo, 14(1), 121-132, 2006

\title{
SYNERGISTIC EFFECT OF VOLATILE OILS AND ANTIBIOTICS AGAINST SOME GRAM POSITIVE AND NEGATIVE PATHOGENIC BACTERIA
}

[8]

\author{
Ghaly ${ }^{1}$, M.F.
}

\begin{abstract}
Eight most currently used antibiotics were examined for their antibacterial properties against Gram-ve bacteria as Pseudomonas aeuroginosa, E. coli, Proteus vulgari and Gram+ve as Staphylococcus aureus, Streptococcus pneumonia. Nitrofurantoin was the most effective against the tested bacteria, the inhibition zones ranged between $16-20 \mathrm{~mm}$ and the MIC between $65-85 \mathrm{ug} / \mathrm{ml}$ followed by ampicillin (11$18 \mathrm{~mm})$, ciprofloxacin $(9-12 \mathrm{~mm})$ and gentamicin $(6-9 \mathrm{~mm})$. The erythromycin was the lowest effective against the tested bacteria. Also, seven volatile oils were applied by contact and fumigation methods to study their effect on the tested bacterial strains. The fumigation method gave the highest inhibitory effect more than contact method and the thyme oil gave maximum inhibitory action (inhibition zone 20$28 \mathrm{~mm}$ ) against all the tested bacteria, and the MIC ranged between $0.1-0.15 \mathrm{mg} / \mathrm{ml}$ followed by marjoram oil (19-25mm) and the MIC between $0.1-0.2 \mathrm{mg} / \mathrm{ml}$, cinnamon oil (12-16mm) and the MIC between $0.2-0.3 \mathrm{mg} / \mathrm{ml}$. Anise and chamomile oils did not gave any response against all the tested bacteria. The combination between thyme and other tested oils gave a synergistic effect for inhibitory action against all the tested bacteria, if compared with thyme oil alone. The combination between thyme and marjoram oil gave the maximum inhibition zones $(20-29 \mathrm{~mm})$, followed by thyme with cinnamon oil $(20-27 \mathrm{~mm})$, thyme with geranium gave $(18-27 \mathrm{~mm})$, thyme with peppermint $(17-27 \mathrm{~mm})$, thyme with chamomile $(16-27 \mathrm{~mm})$ and thyme with anise oil (15-26mm). The combination of thyme oil with different tested antibiotics gave the lowest inhibitory effect than combination between thyme and other volatile oils against all the tested bacteria. The protein and DNA content of treated bacteria with thyme oil were increased by $38.46-47.37 \%$ and $34.26-46.94 \%$ respectivily, if compared by non-treated bacteria.
\end{abstract}

Keywords: Pseudomonas aeuroginosa, E. coli, Proteus vulgaris, Staphylococcus aureus, Streptococcus pneumonia, Antibiotics, Plant extract, Volatile oils

1- Botany Department, Faculty of Science, Zagazig University, Egypt.

(Received November 14, 2005)

(Accepted December 17, 2005) 


\section{INTRODUCTION}

Resistance of bacteria to antimicrobial agents has become a worldwide problem, both in hospitals and in the community (Molstad and Otto, 1999). Essential oil extracts of various plants have been reported to have inhibitory effect against diverse types of microorganisms including Gram-positive and Gram-negative bacteria, fungi and virsuses (Sue $\boldsymbol{e t}$ al 2000). The development of antimicrobial agents has advanced significantly in recent years and a large number of new drugs are available for clinical practice, yet the use of these drugs has caused changes in the bacteria that cause infection resulting in the appearance of drugsresistant strains (Ooishi and Miyao, 1997).

Numerous studies have also shown that many of these oil exert potent antimicrobial effects on a wide variety of human pathogens and food spoilage microorganisms (Abo-Ghalia et al 2004). Diab et al (2004) reported that, the treatment of urinary tract infection by Pseudomonas aeruginosae was completely treated by imipenem and cefotoxime antibiotics.

This study aimed to differentiate between the inhibitory effect of volatile oils, antibiotics either used separetely or in combination between each of them against some pathogenic bacterial (Gram +ve and Gram -ve) strains.

\section{MATERIAL AND METHODS}

\section{Bacterial strains}

All bacterial isolates were provided by Prof. Dr. Hosam Ibrahim El-Sharkawy Prof.of Microbiology, Faculty of Medicine, Zagazig University. Identification of bacterial isolates were carried out by typical colonial morphology and Gram stain then biochemical tests according to Cheesbrough (1985).

\section{Volatile oils used}

Seven volatile oils were used in this study purchased from Sekem company, Egypt. These oils used for testing their antimicrobial activities against bacterial strains. The testing oils were as follows: marjoram (Margorana hortensis), thyme (Thymus vulgaris), geranium (Pelargonium graveolens), peppermint (Mentha piperata), anise (Pimpinella anisum), cinnamon (Cinnamomum zylanicum) and chamomile (Martricaria recutica)

\section{Antimicrobial assay}

Seeded agar plates were prepared using $25 \mathrm{ml}$ of molten Muller-Hinton agar for bacterial growth as described by Bauer, et al (1966). A well of $5 \mathrm{~mm}$ in diameter was made in solidified agar and 10ul of tested oil or combined with antibiotics was added to the well, plates were incubated at $28-30^{\circ} \mathrm{C}$ for $24 \mathrm{~h}$. Oils were mixed with 1-2drops of tween 80 for emulsified before using. Inhibition zones were measured in $\mathrm{mm}$. MIC is recorded as the lowest concentration of the antibiotics that inhibites the growth of tested organisms.

\section{Antibiotics susceptibility test}

Antibiotics susceptibility test was done by the disc-diffusion technique using commercially available antibiotic disc as recommended by Bauer, et al (1966).

Effect of combined between thyme and marjoram oils on protein and DNA content. 
Each bacterial strains was treated with lowest MIC concentration of thyme with marjoram oils and incubated at $28-30^{\circ} \mathrm{C}$ for $24 \mathrm{~h}$., centrifuged and washed several times with sterile distilled water. The pellet was dried at $55-60^{\circ} \mathrm{C}$ then collected for extraction and measuring the protein and DNA content colo urimetrically.

\section{Extraction and measurement of pro- tein}

The dried pellets of the tested bacteria were extracted with $1 \mathrm{~N}(\mathrm{NaOH})$ solution at $70^{\circ} \mathrm{C}$ for $30 \mathrm{~min}$ as recommended by Peiterson, (1977). The extracted protein was determined as described by Lowry, et al (1951) using bovine albumin as a standard protein in concentrations ranging from $10 \mu \mathrm{g}$ to $100 \mu \mathrm{g} / \mathrm{ml}$.

\section{Extraction and measurement of DNA}

DNA was extracted according to Boom, et al (1990). Dried pellets were transferred to epindorff tubes containing $1 \mathrm{ml}$ of TE buffer $(10 \mathrm{mM}$ Tris- $\mathrm{HCl}$ and $1 \mathrm{mM}$ EDTA $\mathrm{pH} 8$ ). The samples were boiled at $100^{\circ} \mathrm{C}$ for $10 \mathrm{~min}$ and cetrifuged at $14000 \mathrm{rpm}$ for $5 \mathrm{~min}$. the supernatant containing DNA was transferred to a new tube and applied to measurement according to Burton, (1968) where it depends on measuring the color developed after treating the extracted DNA with diphenylamine reagent. The absorbance was measured at $600 \mathrm{~nm}$.

\section{RESULTS AND DISCUSSION}

Eight antibiotics namely ampicillin (30 $u g, \mathrm{Am})$, nitrofurantoin $(300 u g, \mathrm{Nt})$ ciprofloxacin (5 $u g, \mathrm{Cp})$, amikacin (3ug, Am), cephradine (30 ug, Ce), gentamy- cin (30 $u g, \mathrm{Gm})$, impenem (10 $u g, \mathrm{Im})$ and erythromycin (30 ug, Er) were used as illustrated in Table (1) with standard disc diffusion method. The presented data revealed that the highest effective antibiotic was obtained by nitrofurantoin against either Gram-ve or Gram+ve bacteria, resulted to inhibition zone ranged between 16-20 mm. Ampicillin represent the second inhibitory effect antibiotic against either Gram-ve or Gram+ve of the tested strain except Staphylococcus aureus, since amikacin gave the same inhibion zone as nitrofurantoin being 16 $\mathrm{mm}$. It is also interesting to mention that, all the tested strain were resistance to erythromycin except Streptococcus pneumonia and Proteus vulgaris .

Gentamycin gave the lowest inhibion zones against Gram-ve bacteria which ranged between 6-8 $\mathrm{mm}$. These results were agreement with Gupta et al (1999) who showed that the susceptibility of Gram-negative bacteria E.coli to nitrfurantoin reach to $70 \%$. David et al (2000) found that $63 \%$ of $E$. coli isolates were resistant to gentamicin, also Fawzy (2004) reported that $34 \%$ of E.coli isolates from diarrhea were sensitive to gentamycin. Diab et al (2004) revealed that 90\% of Pseudomonas aeuroginosa isolates from out patient was sensitive to ciprofloxacin antibiotic. The results in Table (2) illustrated that the MIC values of ampicillin and nitrofurantoin differe according to bacterial isolates, in generally the MIC of nitrofurantoin higher than ampicillin on all the tested bacterial strains.

The efficacy of seven volatile oils on bacterial strains were illustrated by contact method in Table (3) and by fumigation method in Table (4). These results indicated that, the thyme oil with contact 
Table 1. Antibiotics susceptibility test against the tested bacterial strains

\begin{tabular}{|l|ccccccccc|}
\hline \multirow{2}{*}{ Bacterial strains } & \multicolumn{7}{|c|}{ Inhibition zones (mm) } \\
\cline { 2 - 9 } & Am & NT & Cp & Ak & Ce & Gm & Im & Er \\
\hline Gram -ve & & & & & & & & \\
Pseudomonas aeuroginosa & 18 & 20 & 10 & 17 & 12 & 8 & 15 & -ve \\
E.coli & 16 & 18 & 11 & 15 & 10 & 6 & 12 & -ve \\
Proteus vulgaris & 15 & 16 & 9 & 15 & 11 & 8 & 11 & 6 \\
Gram+ve & & & & & & & & \\
Staphylococcus aureus & 11 & 16 & 12 & 16 & 14 & 13 & 13 & $-\mathrm{ve}$ \\
Streptococcus pneumonia & 18 & 18 & 14 & 15 & 12 & 14 & 14 & 7 \\
\hline
\end{tabular}

$\mathrm{Am}=$ ampicillin $\mathrm{Nt}=$ nitrofurantoin $\mathrm{Cp}=$ ciprofloxacin $\mathrm{Ak}=$ amikacin $\mathrm{Ce}=$ cephradine $\mathrm{Gm}=$ gentamicin $\mathrm{Im}=$ imipenem $\mathrm{Er}=$ erythromycin .

Table 2. MIC of ampicillin and nitrofurantoin antibiotics against the tested strains

\begin{tabular}{|l|cc|}
\hline \multicolumn{1}{|c|}{ Bacterial strains } & $\begin{array}{c}\text { Ampicillin (ug/ml) } \\
\text { MIC }\end{array}$ & $\begin{array}{c}\text { Nitrofurantoin (ug/ml) } \\
\text { MI C }\end{array}$ \\
\hline Gram-ve & & 80 \\
Pseudomonas aeuroginosa & 14 & 72 \\
E.coli & 20 & 65 \\
Proteus vulgaris & 18 & \\
Gram+ve & & 85 \\
Staphylococcus aureus & 16 & 82 \\
Streptococcus pneumonia & 18 & \\
\hline
\end{tabular}

MIC = Minimum Inhibitory Concentration. 
Table 3. Effect of different volatile oils against the tested strains by contact method

\begin{tabular}{|l|ccccc|}
\hline \multirow{3}{*}{ Volatile oils } & \multicolumn{5}{|c|}{ Inhibition zones (mm) } \\
\cline { 2 - 6 } & $\begin{array}{c}\text { Pseudomonas } \\
\text { aeuroginosa }\end{array}$ & $\begin{array}{c}\text { E. } \\
\text { coli }\end{array}$ & $\begin{array}{c}\text { Proteus } \\
\text { vulgaris }\end{array}$ & $\begin{array}{c}\text { Staphylococcus } \\
\text { aureus }\end{array}$ & $\begin{array}{c}\text { Streptococcus } \\
\text { pneumonia }\end{array}$ \\
\hline Marjoram & 20 & 19 & 18 & 20 & 18 \\
Thyme & 22 & 22 & 20 & 18 & 17 \\
Geranium & 0 & 12 & 0 & 10 & 9 \\
Peppermint & 0 & 10 & 0 & 9 & 0 \\
Anise & 0 & 0 & 0 & 0 & 0 \\
Cinnamon & 16 & 15 & 14 & 15 & 13 \\
Chamomile & 0 & 0 & 0 & 0 & 0 \\
Control & 0 & 0 & 0 & 0 & 0 \\
\hline
\end{tabular}

Table 4. Effect of different volatile oils against the tested bacterial strains by fumigation method

\begin{tabular}{|l|ccccc|}
\hline \multirow{3}{*}{ Volatile oils } & \multicolumn{5}{|c|}{ Inhibition zones (mm) } \\
\cline { 2 - 6 } & $\begin{array}{c}\text { Pseudomonas } \\
\text { aeuroginosa }\end{array}$ & E.coli & $\begin{array}{c}\text { Proteus } \\
\text { vulgaris }\end{array}$ & $\begin{array}{c}\text { Staphylococcus } \\
\text { aureus }\end{array}$ & $\begin{array}{c}\text { Streptococcus } \\
\text { pneumonia }\end{array}$ \\
\hline Marjoram & 25 & 22 & 20 & 21 & 19 \\
Thyme & 27 & 28 & 23 & 20 & 20 \\
Geranium & 0 & 13 & 0 & 12 & 9 \\
Peppermint & 0 & 12 & 0 & 11 & 8 \\
Anise & 0 & 0 & 0 & 0 & 0 \\
Cinnamon & 16 & 14 & 14 & 13 & 12 \\
Chamomile & 0 & 0 & 0 & 0 & 0 \\
Control & 0 & 0 & 0 & 0 & 0 \\
\hline
\end{tabular}


and fumigation methods was the highest effective against all Gram-negative bacteria followed by marjoram and cinnamon oils, the remaining oils have low or not effect on Gram negative and positive bacteria. On the other hand, marjoram oil was the highest effective against Gram positive followed by thyme and cinnamon oil. There has been increasing interest in the use of natural substances with antimicrobial properties in preference to synthetic substances for controlling diseases (Dac-Vinh et al 2000; Hussain et al 2003; Dorman and Deans, 2004; and Abo-Ghalia et al 2004). These results were agreement with Chao et al (2000) who reported that Gram-ve bacteria have a cell wall covered by an outer membrane composed of lipopolysaccharide (LPS) and some proteins, this structure may prevent either the uptake of the oils or protect the peptidoglycan layer from the oils. The outer LPS membrane of Gram ve bacteria present a permeability barrier to hydrophobic substances that can enter and inhibit the growth of Gram +ve bacteria (White, 1995). Gram +ve bacteria had not the outermembrane and the peptidoglycan layer is on the outside and more available to contact with the oils. On the other hand, Zambonelli et al (2004) suggested that the alterations caused by thymol are due to its ability to damage the cellular membranes and to interfere with the membrane enzymatic reactions which are fundamental for cellular membrane. Bacteriostatic (MIC) effect of thyme, marjoram and cinnamon which selective the most effective oils (by contact method) were tested against selected strains. The results were reported in Table (5) which illustrated that the lowest MIC of the thyme followed by marjoram and cinnamon oils against
Gram positive and negative bacteria. MIC of the thyme oil ranged between $0.1-0.15 \mathrm{mg} / \mathrm{ml}$, whereas marjoram from 0.1-0.2 and cinnamon oil from 0.2-0.3 $\mathrm{mg} / \mathrm{ml}$. Abo-Ghalia et al (2004), reported that the MIC of thyme oil $0.32 \mathrm{mg} / \mathrm{ml}$ against Staphylococcus aureus, Streptococcus pygenes, E. coli and Proteus vulgaris, however Klebsiella sp. and Streptococcus faecalis were inhibited by $0.64 \mathrm{mg} / \mathrm{ml}$. Thyme oil had a bacteriostatic concentrations against $E$. coli and $S$. enteridis at $0.05 \%$ and $0.04 \%$ respectively, as reported by Smith et al (1998).

The data presented in Table (6) clearly show that the highest figures of synergistic inhibitory effect against all the tested strains, which express as inhibition zones $(\mathrm{mm})$ were obtained in the treatment contained equal mixture of thyme and margoram (10ul) than other combination of rest oils. Cappelletty and Rybak (1996) reported that the combinations of antimicrobial agents are considered to be synergistic if the effect of the combination is greater than the effect either agent alone or greater than the sum of the effect of the individual agents. Antagonism results occurred if the combination provides an effect more than the effect of either agent alone or more than the sum of the effects of the individual agents. The combination of thyme oil with different antibiotics were tested and the results in Table (7) revealed that the combination of thyme oil with nitrofuratoin gave the highest inhibitory effect against all tested bacterial strains and the action of thyme oil with all tested antibiotics increase the synergistic inhibitory effect against resistant bacterial isolates with treated antibiotics only. The combination between amoxycillin and $10 \mu l$ anise oil gave a 
Table 5. MIC of thyme, marjoram and cinnamon oils against the tested strains

\begin{tabular}{|l|ccc|}
\hline \multicolumn{1}{|c|}{ Bacterial strains } & $\begin{array}{c}\text { Thyme oil } \\
(\mathrm{mg} / \mathrm{ml})\end{array}$ & $\begin{array}{c}\text { Marjoram } \\
\text { oil (mg/ml) }\end{array}$ & $\begin{array}{c}\text { Cinnamon } \\
\text { oil (mg/ml) }\end{array}$ \\
\hline Gram-ve & & & \\
Pseudomonas aeuroginosa & 0.10 & 0.15 & 0.25 \\
E.coli & 0.15 & 0.20 & 0.30 \\
Proteus vulgaris & 0.10 & 0.15 & 0.20 \\
Gram+ve & & & \\
Staphylococcus aureus & 0.10 & 0.10 & 0.20 \\
Streptococcus pneumonia & 0.15 & 0.10 & 0.25 \\
\hline
\end{tabular}

Table 6. Efficacy of combination between thyme oil and different volatile oils against the tested strains

\begin{tabular}{|l|ccccc|}
\hline \multirow{2}{*}{ Treatment } & \multicolumn{5}{|c|}{ Inhibition zones (mm) } \\
\cline { 2 - 6 } & $\begin{array}{c}\text { Pseudomonas } \\
\text { aeuroginosa }\end{array}$ & E.coli & $\begin{array}{c}\text { Proteus } \\
\text { vulgaris }\end{array}$ & $\begin{array}{c}\text { Staphylococcus } \\
\text { aureus }\end{array}$ & $\begin{array}{c}\text { Streptococcus } \\
\text { pneumonia }\end{array}$ \\
\hline Thyme + marjoram & 29 & 28 & 24 & 20 & 21 \\
Thyme + geranium & 26 & 27 & 22 & 19 & 18 \\
Thyme + peppermint & 27 & 26 & 23 & 20 & 17 \\
Thyme + cinnamon & 27 & 27 & 22 & 20 & 20 \\
Thyme + anise & 26 & 26 & 23 & 18 & 15 \\
Thyme + chamomile & 27 & 27 & 22 & 20 & 16 \\
\hline
\end{tabular}


Table 7. Effect of combination between thyme oil and different antibiotics against the tested strains

\begin{tabular}{|l|ccccc|}
\hline \multirow{2}{*}{ Treatment } & \multicolumn{5}{|c|}{ Inhibition zones (mm) } \\
\cline { 2 - 6 } & $\begin{array}{c}\text { Pseudomonas } \\
\text { aeuroginosa }\end{array}$ & E.coli & $\begin{array}{c}\text { Proteus } \\
\text { vulgaris }\end{array}$ & $\begin{array}{c}\text { Staphylococcus } \\
\text { aureus }\end{array}$ & $\begin{array}{c}\text { Streptococcus } \\
\text { pneumonia }\end{array}$ \\
\hline Thyme + ampicillin & 22 & 20 & 20 & 18 & 17 \\
Thyme + nitrofurantoin & 23 & 22 & 21 & 19 & 21 \\
Thyme + ceprofloxacin & 20 & 20 & 18 & 17 & 17 \\
Thyme + amikin & 21 & 20 & 19 & 18 & 18 \\
Thyme + cephradine & 20 & 20 & 20 & 17 & 19 \\
Thyme + gentamicin & 21 & 21 & 18 & 16 & 18 \\
Thyme + imipenem & 22 & 20 & 19 & 16 & 17 \\
Thyme + erythromycin & 20 & 21 & 20 & 15 & 17 \\
\hline
\end{tabular}

Table 8. Effect of thyme oil (10ul) on protein and DNA content of the tested Gram positive and negative bacteria

\begin{tabular}{|c|c|c|c|c|c|c|}
\hline \multirow[b]{2}{*}{ Bacterial strains } & \multicolumn{3}{|c|}{ Protein content (mg/gm) } & \multicolumn{3}{|c|}{ DNA content (ug/gm) } \\
\hline & Control & Treated & $\begin{array}{c}\% \text { of } \\
\text { increasing }\end{array}$ & Control & Treated & $\begin{array}{c}\% \text { of } \\
\text { increasing }\end{array}$ \\
\hline \\
\hline Pseudomonas & & & & & & \\
\hline aeuroginosa & 40 & 58 & 45.00 & 110 & 148 & 34.55 \\
\hline E.coli & 38 & 56 & 47.37 & 108 & 145 & 34.26 \\
\hline Proteus vulgaris & 41 & 58 & 41.46 & 105 & 142 & 35.24 \\
\hline Gram+ve & & & & & & \\
\hline Staphylococcus & & & & & & \\
\hline aureus & 38 & 54 & 42.10 & 98 & 144 & 46.94 \\
\hline Streptococcus & & & & & & \\
\hline pneumonia & 38 & 54 & 38.46 & 105 & 150 & 42.86 \\
\hline
\end{tabular}

Arab Univ. J. Agric. Sci., 14(1), 2006 
synergistic effect against the multiresistant isolates of $P s$. aeruginosa where this combination increases the inhibition zone of the amoxycillin disc against all chosen multiresistant isolates of Ps.aeruginosa, Zaid (2001). Fawzy (2004) revealed that the combination between antibiotic and 10ul thyme oil gave a synergistic effect against E. coli, Salmonella typhi and Shigella sp.

The effect of thyme oil on protein and DNA content of the tested bacterial strains were reported in Table (8), these results indicated that the protein and DNA content of all the tested bacterial strains increased if compared with non treated chosen isolates, but the percentage of increasing different according to the treated bacterial isolates. The protein and DNA content of Pseudomonas aeuroginosa increased by ratio 45.0 and $34.55 \%$ respectively. The maximum increasing rate of protein and DNA content were attained at E. coli and Staphylococcus aureus by ratio 47.37 and $46.94 \%$, respectively. Wesam, (1994) reported that the cephalosporins treatments were associated with inharmonious effect on the nitrogen metabolism of Bacillus megaterium and E. coli. It increased the protein-N of B. megaterium, on the contrary, the protein- $\mathrm{N}$ was decreased significantly in treated E. coli with cephalosporins. Such inharmonious behavior of cephalosporins can be explained at the basis of the low concentration that increased the protein synthesis through the acceleration of protein building, while the higher concentration decreased the protein synthesis (Egorov, 1985). As regards the effect of thyme oil treatment on DNA content, Fawzy, (2004) revealed that DNA content of treated isolates increased compared with controls. The data report- ed in this concern were linked with the effect of antibiotics on nucleic acid contents. Gottfredsson et al (1995) have shown that the post antibiotic effect (PAE) phase after ceprofloxacin exposure is characterized by a progressive increase in DNA synthesis, which could be due to an increase in DNA repair as a result of persistent antimicrobial action during the post antibiotic effect. Alternatively, the increase in DNA could be due to continued attempts at DNA replication, since DNA polymerase activity is not hampered, but this replication is abortive because the circular DNA cannot be separated as a result of gyrase inhibition.

\section{REFERENCE}

Abo-Ghalia, H.; M. El-Mokadem; A. Ghanem and K. Shaheen (2004). Antimicrobial activity of assential oils of some medicinal plants. Egypt. J. Microbiol. 9: 221-241.

Bauer, A.W.; W.M. Kirby; J.C. Sherris and M. Turk (1966). Antibiotic susceptibility testing by a standerized single disk method. American Journal of Clinical Pathology, 45: 493-496.

Boom, R.; C.J. Sol; M.M. Salimans; P.M. Jansencl and Vander Noordaaj (1990). Rapid and simple method for purification of nucleic acids. J. Clin. Microbiol., 28: 495-503.

Burton, K. (1968). Methods in Enzymology. $12 B$ pp. 215-250, Interscience Publishers. Inc., New York .

Cappelletty, D.M. and M.J. Rybak, (1996). Comparison of methodologies for synergism testing of drug combinations against resistant strains of Pseudomonas aeuroginosa. Antimicrob. Agents. Chemother., 40: 677-683. 
Chao, S.; D. Young and C. Oberg, (2000). Screening for inhibitory activity of essential oils on selected bacteria, fungi and viruses. J. Essent. Oil Res., 12: 639-649.

Cheesbrough, M. (1985). Medical Laboratory Manual for Tropical Countries. Vol. II: Microbiology pp. 225-247. Monica Cheesbrough (Eds), Great Britain Univ. Press, Cambridge.

Dac-Vinh, N.; M. Takacsova; T. Jakubik; H. Minh and T. Nhat (2000). In vitro antibacterial effect of the essential oil of Thymus longiflorus. Microbes, 60 (242): 59-61.

David, G.W.; H. Charlene; J. Jhon; A. Sherry; Z. Shaohua Margie; B. Lance; F. Thomas and S. Julie (2000). Characterization of chloramphenicol and florfenicol resistance in E.coli associated with Bovine diarrhea. J. Clin. Microbiol. 12: 4593-4598.

Diab, A.M.; A.A. Abdelrahman and H.K. Abdel-Latif (2004). Evaluation of currently used antimicrobials to Gramnegative pathogens causing community acquired urinary tract infections. $N$. Egypt. J. Microbiol. 9: 345-356.

Dorman, H.J. and S.G. Deans ( 2004). Chemical composition, antimicrobial and in vitro antioxidant properties of Mondora citriodora, Origanum vulgare, Pelargonium sp and Thymus zygis oils. J. Essent. Oils Res., 16: 145-150.

Egorov, N.S. (1985). Antibiotics A Scientific Approach pp. 324-332. MIR Publishers, Moscow.

Fawzy, A. (2004). Antimicrobial Studies of Essential Oils on Some Bacteria. pp. 52-68. M.Sc. Thesis ,Bot. Dept., Faculty of Science, Zagazig Univ. Egypt.

Gottfredsson, M.; H. Erlendsdottir; A. Gudmundsson and S. Gudmundsson (1995). Different pattern of bacterial
DNA synthesis during post antibiotic effect. Antimicrobial Agents and Chemotherapy. 39: 1314-1319.

Gupta, K.; D. Scholes and W.E. Stamm (1999). Increasing prevelence of antimicrobial resistace among uropathogens causing acute uncomplicated cystitis in women. JAMA, 281:736-738.

Hussain, A.; S.M. Ashour; M.T. ElMokadem and M.M. Refky (2003). Antifungal activity of Egyptian essential oils against some dermatophytes. The African J. of Mycology and Biotechnology. 11 (2): 1-20.

Lowry, O.H.; N.J. Rosebrough; A.L. Farr and R.J. Randall (1951). Protein measurement with folin phenol reagent. J. Biol. Chem., 193: 265-283.

Molstad, S. and C. Otto (1999). Major change in the use of antibiotics following a national programme. Scand. J. Infect. Dis., 31: 191-195.

Ooishi, M. and M. Miyao (1997). Antibiotic sensitivity of recent clinical isolates from patients with ocular infections. Ophthalkologica, 21: 15-24.

Peiterson, N. (1977). Activity of essential ,oils on microorganisms. Biotechinology. Bio., 19: 337-348.

Smith-Palmer, A.; J. Stewart and L. Fyfe (1998). Antimicrobial properties of plant essential oils and essences against five important food borne pathogens. Letters in Applied Microbiology. 26(2): 118-122.

Sue, C.C.; D. Gary Young and J. Craig (2000). Screening for inhibitory activity of essential oils on selected bacteria, fungi and viruses. J. Essent., Oil Res., 12: 639-649.

Wesam, A.A.H. (1994). Studies on the Biological Changes Induced by Certain Antibiotics and Gamma Radiation for Certain Bacteria pp. 82-85. Ph.D. The- 
sis, Dep. of Botany, Zagazig Univ., Egypt.

White, D. (1995). The physiology and biochemistry of prokaryotes. Oxford Univ. Press, New Yourk. J. Essential oil Research, 12: 516-522.

Zaid, A.M. (2001). Studies on Beta Lactamases Producing Bacteria Belonging to Genus Pseudomonas, pp.
96-112. Ph.D. Thesis. Faculty of Science, Zagazig University, Egypt.

Zambonelli, A.; A.Z. Daulerio; A. Severi; S. Benvenuti and A. Bianchi (2004). Chemical composition and fungicidal activity of commercial essential oils of Thymus vulgaris L. J. Essen tial Oil Res., 16: 69-74.

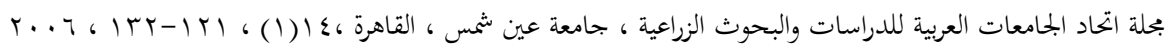

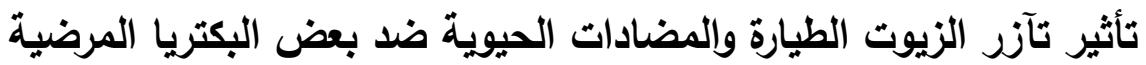
الموجبة والسالبة الجرام

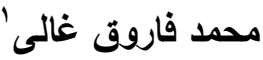

1- قسم النبات - كلية العلوم- جامعة الزقازيق - مصر فعر

الايريسروميسـين اقـل المضــادات الحيويــة

تأثير ا على السلالات البكتيرية المختبرة.

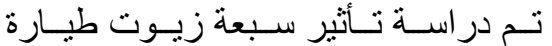

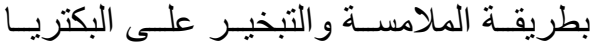

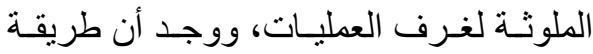

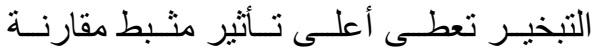

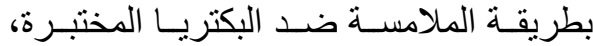

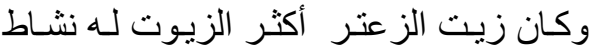

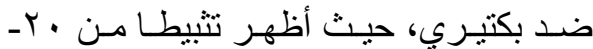

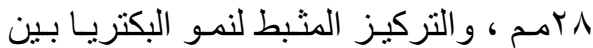

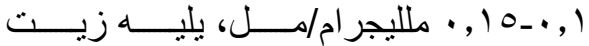

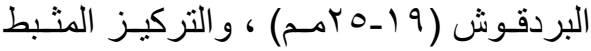

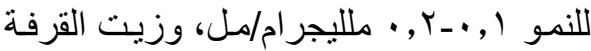

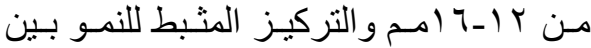

تم استخدام ثماني مضـادات حيويـة شـائعة

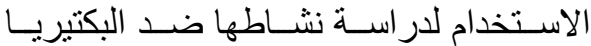

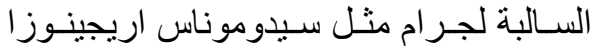

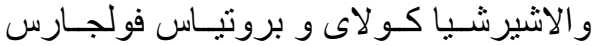
و الموجبة لجرام مثل ستافيلوكوكس اوريوس برس

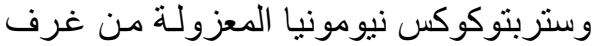
العطليات.وقد وجد أن النيتروفيور انتون اكثر الئر

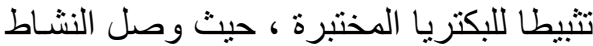

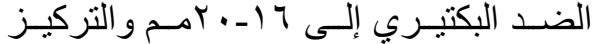

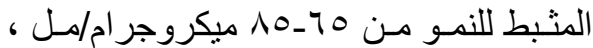

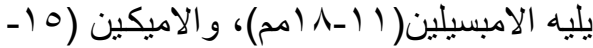

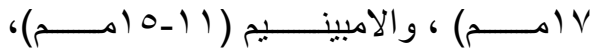

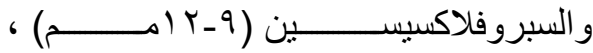

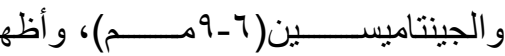


زيت الينسون (10 _ ك rمم). و أظهرت النتائج

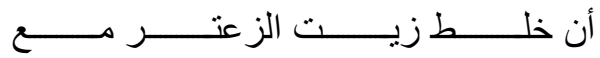

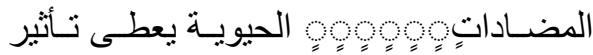
مثبط اقل من الخلط مع الزيوت الطيارة لكل

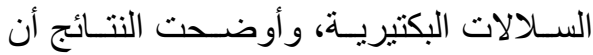

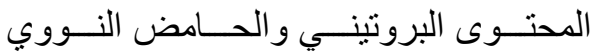

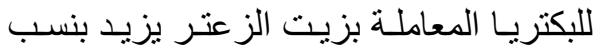

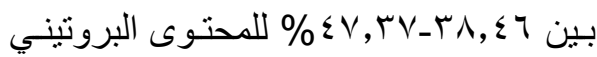

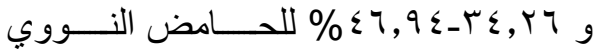
مقارنة بالغير معامل.

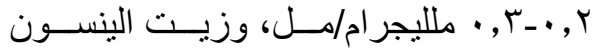
و البابونج ليس لـه تأثثير مثنبط على البكتريـا

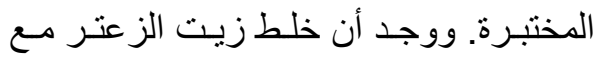

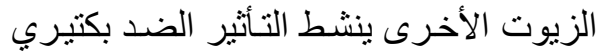

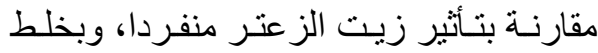

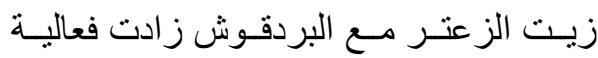

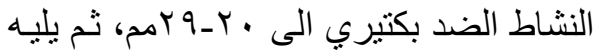

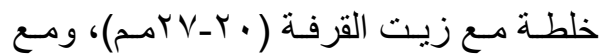

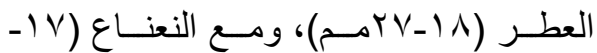
VIr

تحكيم: أ.د راوية فتحى جمال أ.د السيد على السيد 